\title{
molecules
}

ISSN 1420-3049

http://www.mdpi.org

Full Paper

\section{Novel 2-Chloro-8-arylthiomethyldipyridodiazepinone Derivatives with Activity against HIV-1 Reverse Transcriptase ${ }^{\dagger}$}

Nisachon Khunnawutmanotham ${ }^{1}$, Nitirat Chimnoi ${ }^{1}$, Patchareenart Saparpakorn ${ }^{2}$, Pornpan Pungpo $^{3}$, Suda Louisirirotchanakul ${ }^{4}$, Supa Hannongbua ${ }^{2}$ and Supanna Techasakul ${ }^{1,2, *}$

${ }^{1}$ Chulabhorn Research Institute, Vibhavadee-Rangsit Highway, Bangkok 10210, Thailand; E-mails: cnisachon@yahoo.com; E-mail: nitirat@yahoo.com

${ }^{2}$ Department of Chemistry, Faculty of Science, Kasetsart University, Bangkok 10903, Thailand; E-mails: p_saparpakorn@yahoo.com,fscisph@ku.ac.th, supanna@cri.or.th

${ }^{3}$ Department of Chemistry, Faculty of Science, Ubonratchathani University, Ubonratchathani 34190, Thailand; E-mail: pornpan_ubu@yahoo.com

${ }^{4}$ Department of Microbiology, Siriraj Hospital, Mahidol University, Bangkok 10700, Thailand; E-mail: sudaloui@yahoo.com

${ }^{\dagger}$ Paper presented at ECSOC-10, 1-30 November 2006

* Author to whom correspondence should be addressed; E-mail:supanna@cri.or.th

Received: 22 December 2006; in revised form: 18 February 2007 / Accepted: 19 February 2007 / Published: 20 February 2007

Abstract: Based on the molecular modeling analysis against Y181C HIV-1 RT, dipyridodiazepinone derivatives containing an unsubstituted lactam nitrogen and 2chloro-8-arylthiomethyl were synthesized via an efficient route. Some of them were evaluated for their antiviral activity against HIV-1 RT subtype E and were found to exhibit virustatic activity comparable to some clinically used therapeutic agents.

Keywords: Dipyridodiazepinone, HIV-1 RT, antiviral activity 


\section{Introduction}

The introduction of antiretroviral therapy results in delayed progression of HIV-1. The majority of existing therapy methods have targeted the viral replication at reverse transcriptase (RT) and protease enzyme [1,2]. However, the emergence of drug resistance has been observed [3,4], therefore, new therapeutic agents are still needed. Recently, a new class of therapeutic agents has focused on inhibiting HIV entry into cells, CD4 binding, coreceptor binding and membrane fusion such as T-20 [5]. A number of bioactive nucleoside-based compounds against HIV virus have been clinically used [6].

In the clinic, nevirapine (1, Figure 1) [7] monotherapy results in relatively rapid drug resistance due to mutation of the RT enzyme. In an effort to develop a second generation inhibitor with improved activity against mutant RT enzyme, a number of dipyridodiazepinone derivatives have been synthesized and evaluated their activities against HIV-1 RT enzymes [8]. On the basis of a molecular modeling analysis of activity against Y181C HIV-1 RT aimed at modifying the nevirapine structure for higher antiviral activity (Table 1), it was shown that the dipyridodiazepinone derivatives containing unsubstituted lactam nitrogens and a 2-chloro-8-arylthiomethyl (T1 and T2) moiety are effective inhibitors for this mutant enzyme when compared with 68nv, used as reference [9]. The result prompted us to develop an efficient synthetic route to prepare 2-chloro-5,11-dihydro-11-ethyl-8(phenylthio)methyl-6H-dipyrido[3,2-b:2',3'-e][1,4]diazepin-6-one (T1) and 2-chloro-5,11-dihydro-11ethyl-8-(3-methoxy-phenylthio)methyl-6H-dipyrido[3,2-b:2',3'-e][1,4]diazepin-6-one (T2) and to evaluate their anti-HIV-1 activity as well as verifying our hypothesis.

Figure 1. Structure of nevirapine.

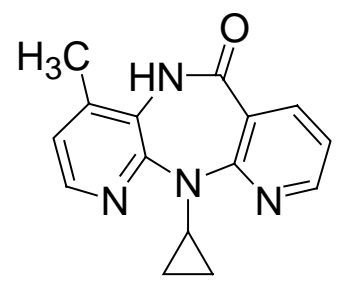

Nevirapine (1)

Table 1. Structure of the proposed compounds and calculated Y181C HIV-1-RT inhibitory affinities.

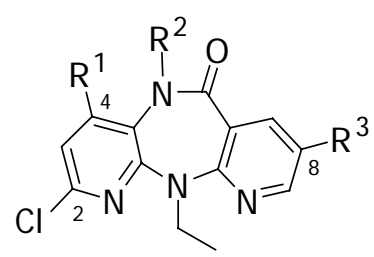

\begin{tabular}{ccccrrrr}
\hline \multirow{2}{*}{ Cpds } & \multirow{2}{*}{$\mathbf{R}^{\mathbf{1}}$} & \multirow{2}{*}{$\mathbf{R}^{2}$} & \multirow{2}{*}{$\mathbf{R}^{3}$} & \multicolumn{3}{c}{ Y181C $\log (\mathbf{1} / \mathbf{C})$} \\
\cline { 5 - 8 } & & & & Expt. $^{\text {a }}$ & Calc. $^{\text {b }}$ & Calc. $^{\mathbf{c}}$ & Calc. $^{\mathbf{d}}$ \\
\hline $\mathbf{6 8 n n v}$ & $\mathrm{H}$ & $\mathrm{CH}_{3}$ & $\mathrm{CH}_{2} \mathrm{SPh}$ & 8.0 & 7.83 & 7.77 & 7.79 \\
$\mathbf{T 1}$ & $\mathrm{H}$ & $\mathrm{H}$ & $\mathrm{CH}_{2} \mathrm{SPh}$ & & 8.19 & 7.96 & 8.01 \\
$\mathbf{T} 2$ & $\mathrm{H}$ & $\mathrm{H}$ & $\mathrm{CH}_{2} \mathrm{SPh}\left(m-\mathrm{OCH}_{3}\right)$ & & 8.25 & 8.05 & 8.17 \\
\hline
\end{tabular}


Table 1. Cont.

\begin{tabular}{|c|c|c|c|c|c|c|c|}
\hline \multirow{2}{*}{ Cpds } & \multirow{2}{*}{$\mathbf{R}^{1}$} & \multirow{2}{*}{$\mathbf{R}^{2}$} & \multirow{2}{*}{$\mathbf{R}^{3}$} & \multicolumn{4}{|c|}{ Y181C $\log (1 / C)$} \\
\hline & & & & Expt. $^{\mathrm{a}}$ & Calc. $^{\text {b }}$ & Calc. $^{c}$ & Calc. $^{\mathrm{d}}$ \\
\hline T3 & $\mathrm{H}$ & $\mathrm{CH}_{2} \mathrm{OH}$ & $\mathrm{CH}_{2} \mathrm{SPh}$ & & 7.70 & 7.55 & 7.79 \\
\hline T4 & $\mathrm{CH}_{3} \mathrm{CH}_{2}$ & $\mathrm{H}$ & $\mathrm{CH}_{2} \mathrm{SPh}$ & & 7.91 & 7.62 & 7.80 \\
\hline T5 & $\mathrm{OCH}_{3}$ & $\mathrm{H}$ & $\mathrm{CH}_{2} \mathrm{SPh}\left(m-\mathrm{OCH}_{3}\right)$ & & 7.70 & 7.47 & 7.58 \\
\hline
\end{tabular}

${ }^{\mathrm{a}}$ [ref. 9], ${ }^{\mathrm{b}}$ Calculated by CoMFA, ${ }^{\mathrm{c}}$ Calculated by CoMSIA, ${ }^{\mathrm{d}}$ Calculated by HQSAR [ref. 10].

\section{Results and Discussion}

\section{Chemistry}

Synthesis of $\mathbf{T 1}$ and $\mathbf{T} 2$ was accomplished from commercially available 2-chloronicotinic acid (2) and 2,6-dichloro-3-nitropyridine (3). The intermediate aminopyridine $\mathbf{4}$ was prepared as shown in Scheme 1. Reaction of 2-chloronicotinyl chloride (5) and 3-amino-2,6-dichloropyridine (6), obtained from reduction of 3 , provided pyridinecarboxamide 7 . Treatment of $\mathbf{7}$ with ethylamine in xylene produced not only the desired 2'-displacement but also competing substitutions of the 2-chloro and 6chloro substituents as significant side reactions. To improve the yield of aminopyridine $\mathbf{4}$, it appears that ethylamine should be introduced before carboxamide formation. Thus, $\mathbf{2}$ was treated with ethylamine in a sealed tube to give 2-(ethylamino)-3-pyridinecarboxylic acid (8) in quantitative yield. Then, acid chloride $\mathbf{9}$ produced from $\mathbf{8}$ was condensed with $\mathbf{6}$ to yield $\mathbf{4}$ in good yield. By this method, an increased and satisfactory yield of $\mathbf{4}$ was obtained.

Scheme 1. Synthesis of the intermediate aminopyridine 4.

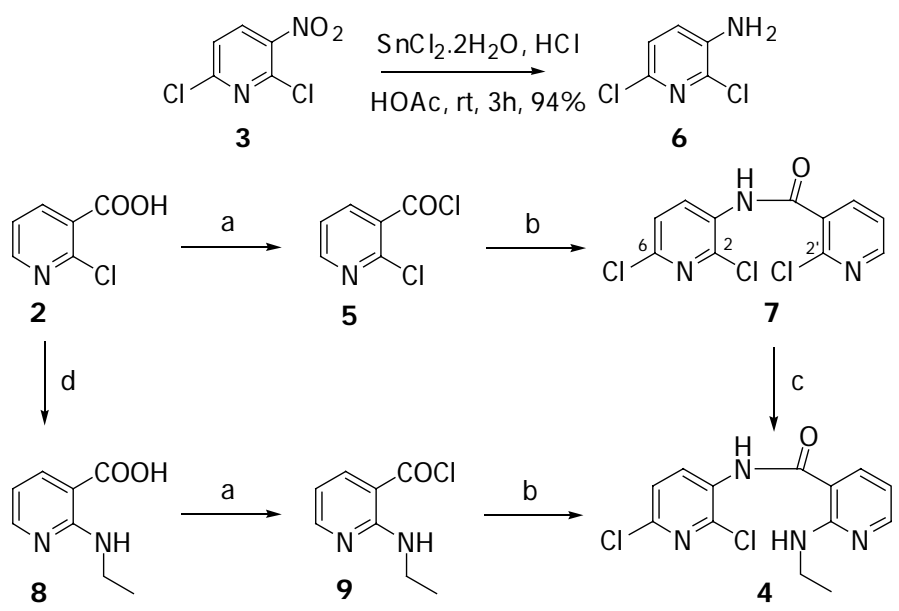

Reagents and conditions: (a) $(\mathrm{COCl})_{2}$, benzene, DMF, rt, 1h; (b) 6, dioxane, cyclohexane, pyridine, rt, $16 \mathrm{~h}, 60 \%$ (from 5 to 7 ) and $80 \%$ (from 9 to 4); (c) $\mathrm{EtNH}_{2}$, xylene, $120^{\circ} \mathrm{C}, 0.5 \mathrm{~h}, 40 \%$; (d) $\mathrm{EtNH}_{2}, 120^{\circ} \mathrm{C}$, 4h, $99 \%$ 
Scheme 2. Synthesis of compounds T1 and T2.<smiles>CCNc1ncccc1C(=O)Nc1ccc(Cl)nc1Cl</smiles>
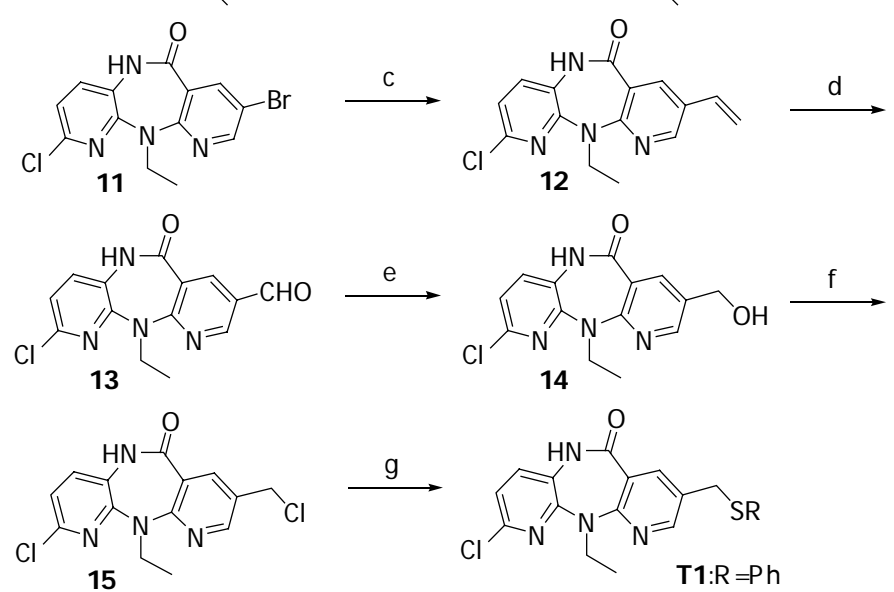
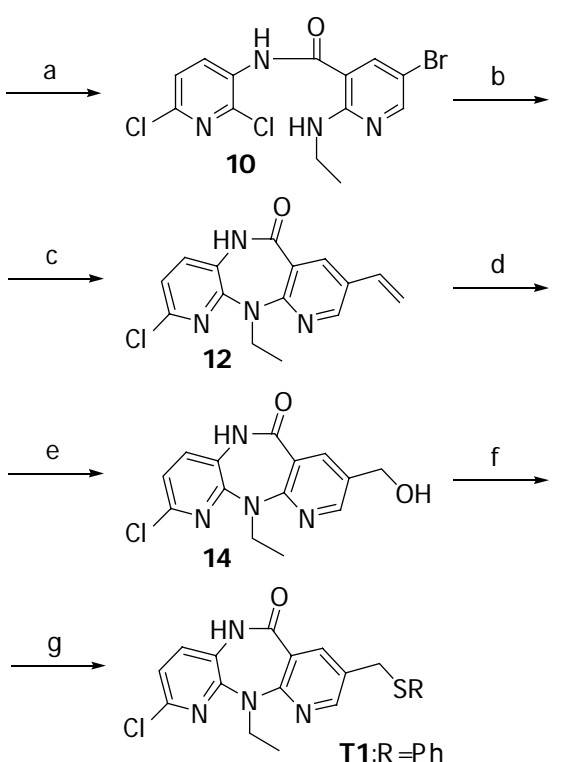

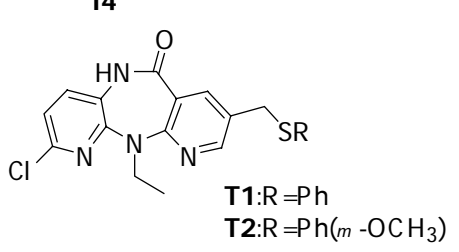

Reagents and conditions: (a) $\mathrm{Br}_{2}$, HOAc, KOAc, rt, 1h, 99\%; (b) NaHMDS, py, $90{ }^{\circ} \mathrm{C}$, 1h, 90\%; (c) $\mathrm{CH}_{2}=\mathrm{CH}-\mathrm{SnBu}_{3}, \mathrm{Pd}\left(\mathrm{PPh}_{3}\right)_{4}, \mathrm{DMF}, 90{ }^{\circ} \mathrm{C}, 1 \mathrm{~h}, 75 \%$; (d) $\mathrm{O}_{3}$, $\mathrm{CH}_{2} \mathrm{Cl}_{2} / \mathrm{MeOH}$, $-78{ }^{\circ} \mathrm{C}$ then $\mathrm{PPh}_{3}$, rt, 1h, 85\%; (e) $\mathrm{NaBH}_{4}, \mathrm{THF}, \mathrm{H}_{2} \mathrm{O}$, rt, 0.5h, 93\%; (f) $\mathrm{SOCl}_{2}, \mathrm{CH}_{2} \mathrm{Cl}_{2}, \mathrm{Et}_{3} \mathrm{~N}, \mathrm{rt}, 87 \%$; (g) $\mathrm{NaH}, \mathrm{RSH}, \mathrm{DMF}, \mathrm{rt}, 1 \mathrm{~h}, 70 \%$ (T1) and 87\% (T2)

The aminopyridine 4 was regioselectively brominated to afford $N$-(2,6-dichloro-3-pyridinyl)-5bromo-2-ethylamino-3-pyridinecarboxamide (10) (Scheme 2). The azepinone ring was formed by treatment with sodium hexamethyldisilazane in pyridine to yield 8-bromo-2-chloro-5,11-dihydro-11ethyl-6H-dipyrido[3,2-b:2',3'-e][1,4]diazepin-6-one (11). Such a ring closure using sodium hydride led to the undesired debrominated product. Coupling of $\mathbf{1 1}$ with vinyltributyltin in the presence of tetrakis(triphenylphosphine)palladium(0) provided the 8-vinyl compound 12, which underwent ozonolysis to give aldehyde 13 in good yield. Reduction of 13 with $\mathrm{NaBH}_{4}$ afforded alcohol 14, which was converted to the corresponding chloride $\mathbf{1 5}$ by treatment with thionyl chloride in dichloromethane. Reaction of $\mathbf{1 5}$ with thiophenolate and 3-methoxythiophenolate in DMF yielded T1 and T2, respectively. Thus T1 and T2 were synthesized from 2-chloronicotinic acid (2) and 2,6-dichloro-3nitropyridine (3) in 10 steps with $26 \%$ and 32\% overall yields, respectively.

\section{Biological Testing}

Compounds T1 and T2, together with some intermediates, were evaluated for their virustatic and virucidal activities against HIV-1 subtype E (CRF01 AE). In addition, the toxicity of the compounds, DMSO and cell controls were also examined. The biological activity of T1 and T2 as well as of intermediates $\mathbf{1 4}$ and $\mathbf{1 5}$ is summarized in Table 2. Compound T1 exhibited virustatic activity at EC 50 $\leq 1 \mu \mathrm{g} / \mathrm{mL}$ for seven days. On the other hand, compound T2 exhibited virustatic activity at $\mathrm{EC}_{50} \leq 1$ $\mu \mathrm{g} / \mathrm{mL}$ during the first four days, but the activity decreased to $\mathrm{EC}_{50} \leq 10 \mu \mathrm{g} / \mathrm{mL}$ by the seventh day. 
Other intermediates did not show virustatic activity. This result suggested that thioaryl group could be involved in regulating virustatic activity. However, all compounds did not show virucidal activity.

Table 2. Virustatic and virucidal activities at 50\% effective concentration $\left(\mathrm{EC}_{50}\right)$ against HIV-1 subtype $\mathrm{E}$.

\begin{tabular}{ccccc}
\hline \multirow{2}{*}{ Cpds } & \multicolumn{2}{c}{$\begin{array}{c}\text { Virustatic } \\
\mathbf{E C}_{\mathbf{5 0}}, \boldsymbol{\mu g} / \mathbf{m L}\end{array}$} & \multicolumn{2}{c}{$\begin{array}{c}\text { Virucidal } \\
\mathbf{E C}_{\mathbf{5 0}}, \boldsymbol{\mu g} / \mathbf{m L}\end{array}$} \\
\cline { 2 - 5 } & Day4 & Day7 & Day4 & Day7 \\
\hline $\mathbf{1 4}$ & $>10$ & $>10$ & $>10$ & $>10$ \\
$\mathbf{1 5}$ & $>10$ & $>10$ & $>10$ & $>10$ \\
$\mathbf{T 1}$ & $<1$ & 1 & $>10$ & $>10$ \\
$\mathbf{T 2}$ & $\leq 1$ & $\leq 10$ & $>10$ & $>10$ \\
\hline
\end{tabular}

Virustatic activity of $\mathbf{T 1}$ and $\mathbf{T} 2$ against HIV-1 subtype E observed in seven days is shown in Figure 2. T1 exhibited comparable virustatic activity to that of AZT, GPOvir and nevirapine at concentration of $1 \mu \mathrm{g} / \mathrm{mL}$ on the fourth day. On the seventh day, T1 exhibited comparable activity to that of nevirapine at a concentration of $1 \mu \mathrm{g} / \mathrm{mL}$ and to that of GPOvir at $10 \mu \mathrm{g} / \mathrm{mL}$, but showed higher activity than AZT at $1 \mu \mathrm{g} / \mathrm{mL}$. T2 was less potent than T1 ( 6-fold) at concentration of $1 \mu \mathrm{g} / \mathrm{mL}$.

Figure 2. Virustatic activity of $\mathbf{T 1}$ and $\mathbf{T} 2$ observed in seven days.

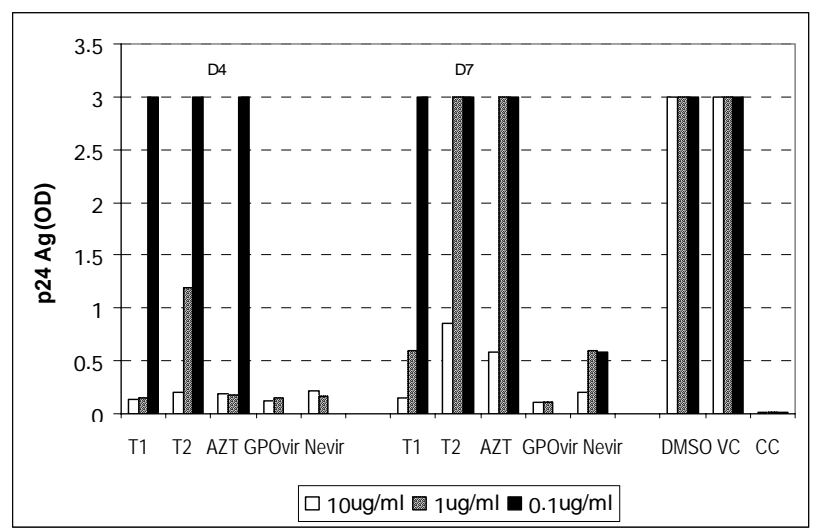

AZT = azidothymidine, GPOvir = analog of three RT inhibitors (nevirapine, lamivudine and stavudine), Nevir = nevirapine, DMSO = DMSO control, VC = virus control and CC = cell control.

\section{Molecular Docking}

In order to investigate the orientation and estimated binding energies of the inhibitors in the enzyme binding site, molecular docking by using Lamarckian genetic algorithm AutoDock 3.05 program [11] was used to dock 68nv, T1 and T2 into the binding pocket of HIV-1 RT (pdb code $1 \mathrm{KLM}$ ) and the results were compared with that of nevirapine, as shown in Table 3 . The grid size was set to $80 x 80 x 80$. A grid spacing of $0.375 \AA$ was used and the numbers of docking runs were set to 50. 
Superimposition of the binding pocket of HIV-1 RT with docked 68nv, T1 and T2, compared with nevirapine (green), is shown in Figure 3. The obtained results demonstrate clearly that $\mathbf{6 8 n v}$ and both T1 and T2 oriented their structures in the HIV-1 RT binding site similar to nevirapine. However, the final docked energies and free energies of binding of both $\mathbf{T} \mathbf{1}$ and $\mathbf{T} \mathbf{2}$ which are the same as those of 68nv with the value of about $\pm 0.5 \mathrm{kcal} / \mathrm{mol}$ are much lower than that of nevirapine by about 4 $\mathrm{kcal} / \mathrm{mol}$. The explanation for this might be the fact that rotatable thiophenyl side chain in the three compounds can interact with the residues in the binding site such as Lys103, Leu234, His235 and Tyr318. However, the docked orientations of $\mathbf{T 1}$ and $\mathbf{T} 2$ revealed that the lack of methyl group at $\mathrm{R}^{2}$ caused a slight move upwards of the $\mathbf{T 1}$ and $\mathbf{T} 2$ structures and make the adjustment of ethyl group attached at diazepinone ring to form the attractive interaction with Val189. Furthermore, methoxy group attached in thiophenyl side chain of T2 also interacts with Val106. This can significantly contribute to the conformational change of the whole enzyme structure, and consequently reduce catalytic efficiency of the enzyme.

Table 3. The docked energy and free energy of binding (kcal/mol) of $\mathbf{T 1}$ and $\mathbf{T} 2$ as compared with nevirapine and $\mathbf{6 8 n v}$.

\begin{tabular}{ccc}
\hline Cpds & $\begin{array}{c}\text { Final Docked Energy } \\
\text { (kcal/mol) }\end{array}$ & $\begin{array}{c}\text { Free Energy of Binding } \\
\text { (kcal/mol) }\end{array}$ \\
\hline Nevirapine & -11.88 & -11.24 \\
$\mathbf{6 8 n v}$ & -15.92 & -15.03 \\
T1 & -15.58 & -14.47 \\
T2 & -16.37 & -14.82 \\
\hline
\end{tabular}

Figure 3. The binding pocket of enzyme HIV-1 RT with 68nv, T1 and T2 (atom type color) compared with nevirapine (green).

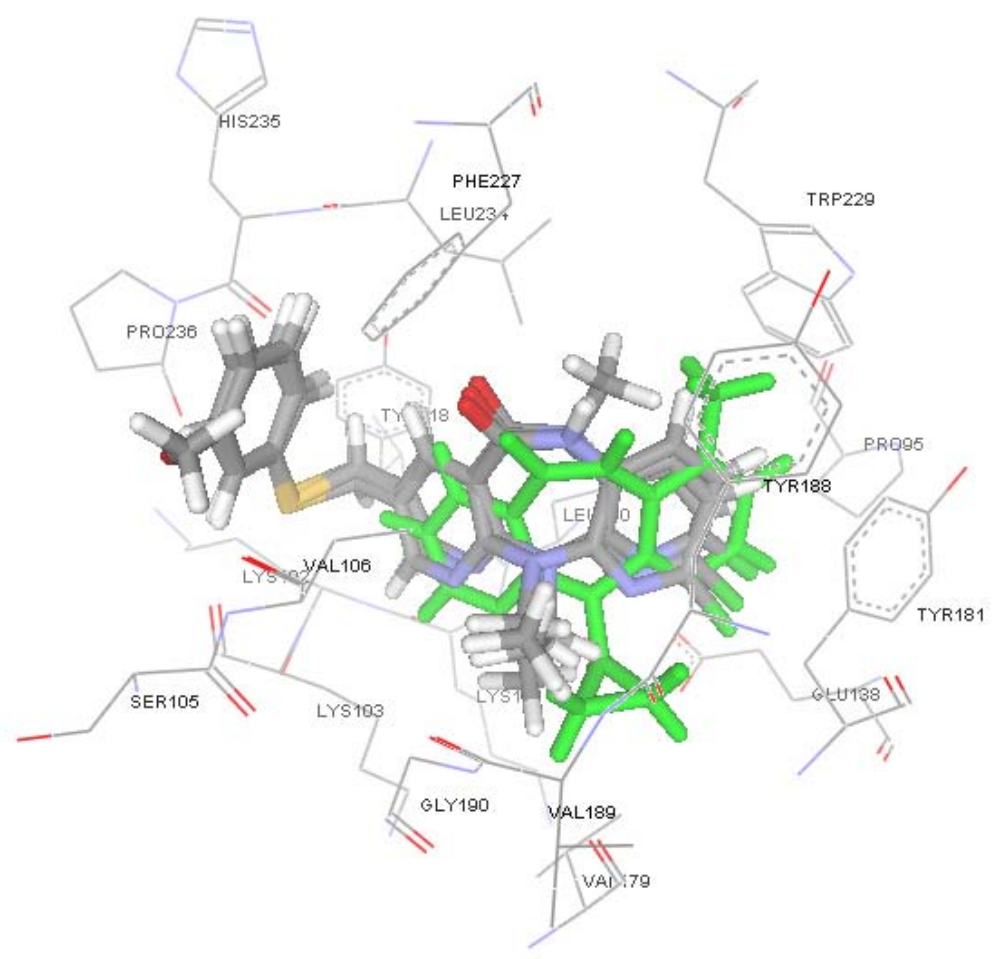




\section{Conclusions}

In summary, two dipyridodiazepinone derivatives, $\mathbf{T} 1$ and $\mathbf{T} 2$, were synthesized based on a molecular modeling study and were found to exhibit virustatic activity against HIV-1 RT subtype E at $2.5 \mu \mathrm{M}(1 \mu \mathrm{g} / \mathrm{mM})$ and $23.5 \mu \mathrm{M}(10 \mu \mathrm{g} / \mathrm{mL})$, respectively.

\section{Experimental Section}

\section{General}

The ${ }^{1} \mathrm{H}$ - and ${ }^{13} \mathrm{C}-\mathrm{NMR}$ spectra were recorded on a Varian Gemini 2000 spectrometer operating at 200 and $50 \mathrm{MHz}$, respectively. Chemical shifts were recorded as $\delta$ values in ppm referenced to the solvent. Coupling constants $(J)$ are given in Hertz. Infrared (IR) spectra were recorded in $\mathrm{cm}^{-1}$ on a Perkin Elmer 1760x FT-IR spectrometer. Mass spectra were obtained on a Finnigan Polaris GCQ mass spectrometer and accurate masses (HRMS) were obtained on a Bruker Micro TOF in ESI positive mode. Melting points (m.p.) were determined on a SMP3 melting point apparatus and are reported in ${ }^{\circ} \mathrm{C}$ uncorrected. Column chromatography was performed on Scharlau silica gel 60 (70-230 mesh).

\section{3-Amino-2,6-dichloropyridine (6)}

A solution of $\mathrm{SnCl}_{2} \cdot 2 \mathrm{H}_{2} \mathrm{O}(970 \mathrm{mg}, 4.3 \mathrm{mmol})$ in concentrated $\mathrm{HCl}(0.8 \mathrm{~mL})$ was added dropwise to a stirred solution of 2,6-dichloro-3-nitropyridine (250 mg, $1.3 \mathrm{mmol}$ ) in acetic acid (2.6 mL) and the mixture was stirred for 3 hours at room temperature. Then the mixture was cooled in ice bath, and water was added. After stirring for an additional half an hour, the mixture was made basic ( $\mathrm{pH} 12$ ) with aqueous $50 \%$ sodium hydroxide. The reaction mixture was extracted with $\mathrm{CH}_{2} \mathrm{Cl}_{2}$ and the combined organic layers were washed with water, dried $\left(\mathrm{Na}_{2} \mathrm{SO}_{4}\right)$ and concentrated under reduced pressure to give 6 (200 mg, 94.8\%) as white solid which could be used directly in the next step. Recrystallization from hexane/ $\mathrm{CH}_{2} \mathrm{Cl}_{2}$ afforded needles, m.p. $121-122{ }^{\circ} \mathrm{C}$; FTIR (KBr) $v_{\max }$ : 3460, 3338, 1619, 1559, 1454, 1311, 1145, $720 \mathrm{~cm}^{-1}$; ${ }^{1} \mathrm{H}-\mathrm{NMR}\left(\mathrm{CDCl}_{3}\right) \delta: 7.06$ (d, J=1.47, 2H); ${ }^{13} \mathrm{C}-\mathrm{NMR}$ $\left(\mathrm{CDCl}_{3}\right) \delta:$ 138.8, 137.3, 134.6, 125.1, 123.6; MS (EI), $\mathrm{m} / \mathrm{z}$ (relative intensity): $162\left(\mathrm{M}^{+}, 100\right), 126$ (20), 99 (10), 64 (30); HRMS (ESI-TOF) calcd. for $\mathrm{C}_{5} \mathrm{H}_{5} \mathrm{Cl}_{2} \mathrm{~N}_{2}[\mathrm{M}+\mathrm{H}]^{+}$162.9824; found: 162.9824.

\section{2-(Ethylamino)-3-pyridine carboxylic acid (8)}

A stirred mixture of 2-chloronicotinic acid (2) (300 mg, $1.9 \mathrm{mmol}$ ), ethylamine (1.3 mL, 19.1 mmol) was heated at $120{ }^{\circ} \mathrm{C}$ in a sealed vessel for 4 hours. After cooling down the ethylamine was removed and the residue was purified by silica gel column chromatography (30\% methanol/ethyl acetate) to give 8 (315 mg, 99.7\%) as a white solid, m.p. 178-180 ${ }^{\circ} \mathrm{C}$; FTIR (KBr) $v_{\text {max }}$ : 3474, 3228, 1636, 1557, 1341, 1239; ${ }^{1} \mathrm{H}-\mathrm{NMR}\left(\mathrm{DMSO}_{-} \mathrm{d}_{6}\right.$ ) $\delta: 8.20$ (dd, $J=4.8,1.8,1 \mathrm{H}$ ), 8.04 (dd, $J=7.7,1.8 \mathrm{~Hz}$, $1 \mathrm{H}), 6.50$ (dd, $J=7.6,5.1,1 \mathrm{H}$ ), 4.81 (br s, $1 \mathrm{H}$ ), 3.43 (q, $J=6.9,2 \mathrm{H}$ ), 1.15 (t, $J=6.9,3 \mathrm{H}$ ); ${ }^{13} \mathrm{C}-\mathrm{NMR}$ (DMSO-d ${ }_{6}$ ) $\delta: 169.3,158.4,153.0,140.1,110.8,106.9,35.1,15.0$; MS (EI), m/z (relative intensity): 
167 ( $\left.\mathrm{M}^{+}+1,20\right), 151$ (60), 133 (100), 122 (30), 93 (50), 78 (96); HRMS (ESI-TOF) calcd. for $\mathrm{C}_{8} \mathrm{H}_{11} \mathrm{~N}_{2} \mathrm{O}_{2}[\mathrm{M}+\mathrm{H}]^{+}$167.0815; found: 167.0812 .

\section{N-(2,6-Dichloro-3-pyridinyl)-2-ethylamino-3-pyridinecarboxamide (4)}

A stirred solution of 8 (315 $\mathrm{mg}, 1.9 \mathrm{mmol})$, in benzene $(10 \mathrm{~mL}$ ) was treated with oxalyl chloride ( $0.35 \mathrm{ml}, 4.1 \mathrm{mmol}$ ) followed by a catalytic amount of DMF (2 drops) and the mixture was stirred at room temperature for 1 hour. Then the solvent was removed under reduced pressure to afford acid chloride 9 as yellow solid. This acid chloride was redissolved in 1,4-dioxane (10 mL) and added dropwise to a solution of 6 (200 mg, $1.2 \mathrm{mmol})$ in 1,4-dioxane $(3 \mathrm{~mL})$, cyclohexane $(2 \mathrm{~mL})$ and pyridine $(0.2 \mathrm{~mL}, 2.4 \mathrm{mmol})$. After stirring at room temperature for 16 hours, the resultant precipitate was filtered. The solid was redissolved in $\mathrm{CH}_{2} \mathrm{Cl}_{2}$ and washed with saturated aqueous $\mathrm{NaHCO}_{3}$. The organic layer was washed with water, dried $\left(\mathrm{Na}_{2} \mathrm{SO}_{4}\right)$ and concentrated under reduced pressure. The residue was purified by silica gel column chromatography (15\% EtOAc/hexane) to yield 4 (308 mg, 80.7\%) as a pale yellow solid, m.p. $119-120{ }^{\circ} \mathrm{C}$; FTIR (KBr) $v_{\max }$ : 3431, 3351, 1660, 1572, 1504, 1301, 1235, 1122, 770; ${ }^{1} \mathrm{H}-\mathrm{NMR}\left(\mathrm{CDCl}_{3}\right) \delta: 8.77$ (d, $\left.J=7.3,1 \mathrm{H}\right), 8.33$ (d, J=4.4, 1H), 8.20 (s, 1H), 7.97 (br t, 1H), 7.74 (d, $J=7.3,1 \mathrm{H}$ ), 7.34 (d, $J=8.1,1 \mathrm{H}$ ), 6.60 (dd, $J=7.3,4.4,1 \mathrm{H}), 3.61-3.48$ (m, 2H), 1.29 (t, $J=7.0,3 \mathrm{H}) ;{ }^{13} \mathrm{C}-\mathrm{NMR}\left(\mathrm{CDCl}_{3}\right) \delta: 166.4,158.1,153.4,143.5,138.7,135.3,131.2,130.9,123.6$, 110.5, 108.0, 35.8, 14.7; MS (EI), m/z (relative intensity): $310\left(\mathrm{M}^{+}, 20\right), 275$ (25), 149 (35), 131 (100), 119 (20); HRMS (ESI-TOF) calcd. for $\mathrm{C}_{13} \mathrm{H}_{13} \mathrm{Cl}_{2} \mathrm{~N}_{4} \mathrm{O}$ [M+H] $]^{+}$311.0461; found: 311.0464.

\section{N-(2,6-Dichloro-3-pyridinyl)-5-bromo-2-ethylamino-3-pyridinecarboxamide (10)}

A solution of $\mathrm{Br}_{2}(0.06 \mathrm{~mL}, 1.17 \mathrm{mmol})$ in acetic acid $(1 \mathrm{~mL})$ was added dropwise to a stirred solution of 4 (355 mg, $1.14 \mathrm{mmol}$ ), and potassium acetate (134 mg, $1.36 \mathrm{mmol}$ ) in acetic acid (15 mL). After 15 minutes, to the reaction mixture was added water and the precipitate was collected by suction filtration and washed with water for several times to provide $\mathbf{1 0}$ (435 $\mathrm{mg}, 98.0 \%$ ) as a yellow solid, m.p. 193-194 ${ }^{\circ} \mathrm{C}$; FTIR (KBr), $v_{\max }$ : 3439, 3336, 1673, 1575, 1506, 1302, 1248, 787, 528; ${ }^{1} \mathrm{H}-\mathrm{NMR}$ $\left(\mathrm{CDCl}_{3}\right) \delta: 8.69$ (d, $\left.J=8.8,1 \mathrm{H}\right), 8.33$ (d, $\left.J=2.2,1 \mathrm{H}\right), 8.10$ (br s, $\left.1 \mathrm{H}\right), 7.89$ (br t, $\left.1 \mathrm{H}\right), 7.79$ (d, $J=2.2$, $1 \mathrm{H}), 7.30$ (d, $J=8.1,1 \mathrm{H}), 3.58-3.44$ (m, 2H), 1.27 (t, $J=7.3,3 \mathrm{H}) ;{ }^{13} \mathrm{C}-\mathrm{NMR}\left(\mathrm{CDCl}_{3}\right) \delta: 165.4,156.5$, 154.2, 139.1, 137.4, 131.7, 130.7, 123.8, 109.6, 103.9, 36.1, 14.6; MS (EI), $\mathrm{m} / \mathrm{z}$ (relative intensity): 388 (M+, 60), 373 (15), 353 (20), 227 (70), 209 (60); HRMS (ESI-TOF) calcd. for $\mathrm{C}_{13} \mathrm{H}_{12} \mathrm{BrCl}_{2} \mathrm{~N}_{4} \mathrm{O}$ $[\mathrm{M}+\mathrm{H}]^{+}$388.9566; found: 388.9579 .

\section{8-Bromo-2-chloro-5,11-dihydro-11-ethyl-6H-dipyrido[3,2-b:2',3'-e][1,4]diazepin-6-one (11)}

A solution of 10 (440 mg, $1.13 \mathrm{mmol})$ in pyridine $(10 \mathrm{~mL})$ was heated at $90^{\circ} \mathrm{C}$ under a nitrogen atmosphere. Then the solution was added $0.6 \mathrm{M}$ sodium bis(trimethylsilyl)amide in toluene (6.3 $\mathrm{mL}$, $3.7 \mathrm{mmol}$ ) and the mixture was stirred at $90{ }^{\circ} \mathrm{C}$ for 15 minutes. After cooling down, the mixture was poured into ice water and stirred for additional 2 hours. The precipitate was filtered and washed with water to afford 11 (370 mg, 92.8\%) as a yellow solid, m.p. 263-264 ${ }^{\circ} \mathrm{C}$; FTIR (KBr) v max: 3195, 3074, 2972, 1665, 1575, 1456, 1381, 1226, 687, 630; ${ }^{1} \mathrm{H}-\mathrm{NMR}\left(\mathrm{CDCl}_{3}\right) \delta: 8.53$ (br s, $\left.1 \mathrm{H}\right), 8.49$ (d, $J=2.2$, 
1H), 8.24 (d, $J=2.2,1 \mathrm{H}$ ), 7.27 (d, $J=8.1,1 \mathrm{H}$ ), 7.06 (d, $J=8.1,1 \mathrm{H}), 4.81$ (q, $J=7.3,2 \mathrm{H}), 1.25$ (t, $J=7.3$, 3H); ${ }^{13} \mathrm{C}-\mathrm{NMR}\left(\mathrm{DMSO}_{\mathrm{d}}\right.$ ) $\delta: 165.4,156.8,151.8,150.5,143.0,142.6,133.3,126.3,122.2,120.4$, 113.6, 41.5, 13.4; MS (EI), m/z (relative intensity): 352 ( $\left.\mathrm{M}^{+}, 80\right), 337$ (42), 324 (75), 309 (20); HRMS (ESI-TOF) calcd. for $\mathrm{C}_{13} \mathrm{H}_{11} \mathrm{BrClN}_{4} \mathrm{O}[\mathrm{M}+\mathrm{H}]^{+}$352.9799; found: 352.9803 .

\section{2-Chloro-5,11-dihydro-11-ethyl-8-vinyl-6H-dipyrido[3,2-b:2',3'-e][1,4]diazepin-6-one (12)}

A solution of $\mathbf{1 1}(500 \mathrm{mg}, 1.4 \mathrm{mmol})$ in $\mathrm{DMF}(7 \mathrm{~mL})$ was treated with tetrakis(triphenylphosphine)palladium $(0)(70 \mathrm{mg}, 0.06 \mathrm{mmol})$ followed by vinyl tributyltin $(1 \mathrm{~mL}$, $3.42 \mathrm{mmol}$ ) and heated at $100{ }^{\circ} \mathrm{C}$ under nitrogen atmosphere for half an hour. After cooling down, the reaction mixture was poured into water and extracted with ethyl acetate. The combined organic layers were washed with $15 \%$ aqueous ammonia, brine and water, then dried $\left(\mathrm{Na}_{2} \mathrm{SO}_{4}\right)$ and concentrated under reduced pressure. The residue was purified by silica gel column chromatography (30\% EtOAc/hexane) to provide 12 (318 mg, 74.6\%) as a yellow solid, m.p. 201-202 ${ }^{\circ} \mathrm{C}$; FTIR (KBr) $v_{\max }$ : 3195, 2965, 1665, 1585, 1455, 1383, 1239, 688; ${ }^{1} \mathrm{H}-\mathrm{NMR}\left(\mathrm{CDCl}_{3}\right)$ $\delta: 9.37$ (s, 1H), 8.46 (d, J=2.2, 1H), 8.20 (d, $J=2.2,1 \mathrm{H}), 7.35$ (d, $J=8.1,1 \mathrm{H}), 7.04$ (d, $J=8.1,1 \mathrm{H}), 6.66$ (dd, $J=17.6,11.0,1 \mathrm{H}), 5.78$ (d, $J=17.6,1 \mathrm{H}$ ), 5.35 (d, $J=11.0,1 \mathrm{H}), 4.22$ (q, $J=7.3,2 \mathrm{H}), 1.27$ (t, $J=7.3,3 \mathrm{H}) ;{ }^{13} \mathrm{C}-\mathrm{NMR}\left(\mathrm{CDCl}_{3}\right) \delta$ : 168.8, 157.9, 151.9, 150.1, 145.1, 137.7, 131.9, 131.8, 128.8, 125.0, 119.7, 119.6, 115.8, 42.1, 13.7; MS (EI), m/z (relative intensity): 300 ( $\left.\mathrm{M}^{+}, 100\right), 285$ (35), 272 (92), 257 (35); HRMS (ESI-TOF) calcd. for $\mathrm{C}_{15} \mathrm{H}_{14} \mathrm{ClN}_{4} \mathrm{O}[\mathrm{M}+\mathrm{H}]^{+}$301.0851; found: 301.0855 .

\section{2-Chloro-5,11-dihydro-11-ethyl-8-formyl-6H-dipyrido[3,2-b:2',3'-e][1,4]diazepin -6-one (13)}

A cooled $\left(-78{ }^{\circ} \mathrm{C}\right)$ solution of $\mathbf{1 2}(343 \mathrm{mg}, 1.14 \mathrm{mmol})$ in $1: 1 \mathrm{CH}_{2} \mathrm{Cl}_{2}-\mathrm{MeOH}(20 \mathrm{~mL})$ was treated with $\mathrm{O}_{3}$ for 30 minutes. After the completion of reaction, the solution was purged with $\mathrm{O}_{2}$ for 5 minutes. Then the reaction mixture was stirred with triphenylphosphine (598 mg, $2.28 \mathrm{mmol}$ ) for additional 1 hour at room temperature. The solvent was removed under reduced pressure and the residue was purified by silica gel column chromatography (30\%EtOAc/hexane) to yield $\mathbf{1 3}$ (295 mg, 85.4\%) as a yellow solid, m.p. 216-217 ${ }^{\circ} \mathrm{C}$; FTIR (KBr) $v_{\max }$ : 3203, 2939, 1702, 1674, 1596, 1456, 1354, 1231, 975, 692; ${ }^{1} \mathrm{H}-\mathrm{NMR}\left(\mathrm{CDCl}_{3}\right) \delta$ : 10.02 (s, $\left.1 \mathrm{H}\right), 9.53$ (s, 1H), 8.60 (d, J=2.2, 1H), 8.64 (d, $J=2.2,1 \mathrm{H}), 7.41$ (d, $J=8.1,1 \mathrm{H}), 7.13$ (d, $J=8.1,1 \mathrm{H}), 4.34$ (q, $J=7.0,2 \mathrm{H}), 1.32(\mathrm{t}, J=7.0,3 \mathrm{H}) ;{ }^{13} \mathrm{C}-\mathrm{NMR}$ $\left(\mathrm{CDCl}_{3}\right) \delta:$ 188.6, 168.1, 162.1, 153.8, 149.9, 145.3, 142.3, 132.3, 126.9, 125.0, 120.8, 118.8, 43.0, 13.7; MS (EI), m/z (relative intensity): $302\left(\mathrm{M}^{+}, 80\right), 287$ (30), 274 (100), 260 (30), 245 (35); HRMS (ESI-TOF) calcd. for $\mathrm{C}_{14} \mathrm{H}_{12} \mathrm{ClN}_{4} \mathrm{O}_{2}[\mathrm{M}+\mathrm{H}]^{+}$303.0643; found: 303.0645 .

2-Chloro-5,11-dihydro-11-ethyl-8-hydroxymethyl-6H-dipyrido[3,2-b:2',3'-e][1,4]diazepin-6-one (14)

To a solution of 13 (228 mg, $0.75 \mathrm{mmol})$ in THF (12 mL) were added water $(0.1 \mathrm{~mL})$ and sodium borohydride (28.5 mg, $0.75 \mathrm{mmol}$ ). The mixture was stirred for half an hour, then diluted with water. THF was removed under reduced pressure and the precipitate was filtered and washed with water to yield 14 (214 mg, 93\%) as a white solid, m.p. 197-198 ${ }^{\circ} \mathrm{C}$; FTIR (KBr) v $v_{\max }$ : 3319, 3191, 2959, 1666, 1590, 1456, 1390, 1232, 1041; ${ }^{1} \mathrm{H}-\mathrm{NMR}$ (acetone- $\mathrm{d}_{6}$ ) $\delta: 9.50$ (br s, 1H), 8.46 (d, J=2.2, 1H), 8.11 (d, 
$J=2.2,1 \mathrm{H}), 7.60$ (d, $J=8.1,1 \mathrm{H}), 7.18$ (d, $J=8.1,1 \mathrm{H}), 4.65$ (d, $J=5.13,2 \mathrm{H}), 4.56$ (t, $J=5.86,1 \mathrm{H}), 4.15$ (q, $J=7.3,2 \mathrm{H}$ ), 1.21 (t, $J=7.3,3 \mathrm{H}$ ); ${ }^{13} \mathrm{C}-\mathrm{NMR}$ (acetone- $\mathrm{d}_{6}$ ) $\delta: 167.8,158.7,152.7,151.0,144.5,140.3$, 134.1, 133.4, 127.3, 121.2, 120.5, 61.5, 42.4, 14.0; MS (EI), $\mathrm{m} / \mathrm{z}$ (relative intensity): 304 ( $\left.\mathrm{M}^{+}, 69\right), 289$ (39), 276 (100), 261 (29), 247 (20), 164 (31); HRMS (ESI-TOF) calcd. for $\mathrm{C}_{14} \mathrm{H}_{14} \mathrm{ClN}_{4} \mathrm{O}_{2}[\mathrm{M}+\mathrm{H}]^{+}$ 305.0800; found: 305.0805 .

2-Chloro-5,11-dihydro-11-ethyl-8-chloromethyl-6H-dipyrido[3,2-b:2',3'-e][1,4]diazepin-6-one (15)

A suspension of $14(177 \mathrm{mg}, 0.58 \mathrm{mmol})$ in $\mathrm{CH}_{2} \mathrm{Cl}_{2}(100 \mathrm{~mL})$ was treated with thionyl chloride $(0.3 \mathrm{~mL})$ followed by triethylamine $(1 \mathrm{~mL})$. The reaction mixture was stirred at room temperature for 1 hour and a clear solution was obtained. Then, saturated aqueous $\mathrm{NaHCO}_{3}$ was added and the mixture was extracted with $\mathrm{CH}_{2} \mathrm{Cl}_{2}$. The organic layer was washed with water, then dried $\left(\mathrm{Na}_{2} \mathrm{SO}_{4}\right)$ and concentrated under reduced pressure. The residue was purified by silica gel column chromatography (20\%EtOAc/hexane) to give 15 (163 mg, 87\%) as a pale yellow solid, m.p. 226-227 ${ }^{\circ} \mathrm{C}$; FTIR (KBr) $v_{\max }$ : 3195, 2969, 1671, 1588, 1455, 1382, 1247, 699; ${ }^{1} \mathrm{H}-\mathrm{NMR}\left(\mathrm{CDCl}_{3}\right)$ 8: 9.15 (br s, $\left.1 \mathrm{H}\right), 8.47$ (d, $J=2.9,1 \mathrm{H}$ ), 8.19 (d, $J=2.9,1 \mathrm{H}), 7.34$ (d, $J=8.1,1 \mathrm{H}), 7.06$ (d, $J=8.1,1 \mathrm{H}), 4.58$ (s, 2H), 4.23 (q, $J=7.3$, 2H), 1.27 (t, $J=7.3,3 \mathrm{H})$; ${ }^{13} \mathrm{C}-\mathrm{NMR}\left(\mathrm{CDCl}_{3}\right) \delta: 168.3,158.7,151.7,151.5,145.2,141.4,131.9,128.3$, 125.0, 119.9, 119.6, 42.3, 42.2, 13.7; MS (EI), m/z (relative intensity): 322 ( $\left.\mathrm{M}^{+}, 54\right), 307$ (31), 294 (62), 287 (37), 259 (100), 244 (28), 231 (21); HRMS (ESI-TOF) calcd. for $\mathrm{C}_{14} \mathrm{H}_{13} \mathrm{Cl}_{2} \mathrm{~N}_{4} \mathrm{O}[\mathrm{M}+\mathrm{H}]^{+}$ 323.0461; found: 323.0470 .

2-Chloro-5,11-dihydro-11-ethyl-8-(phenylthio)-methyl-6H-dipyrido[3,2-b:2',3'-e][1,4]diazepin-6-one (T1)

A solution of thiophenol $(0.1 \mathrm{ml}, 0.97 \mathrm{mmol})$ in DMF $(2 \mathrm{~mL})$ was treated with $60 \%$ sodium hydride (65 mg, $1.6 \mathrm{mmol}$ ) under a $\mathrm{N}_{2}$ atmosphere. After 10 minutes, a solution of 15 (100 mg, 0.31 $\mathrm{mmol}$ ) in DMF (3 $\mathrm{mL}$ ) was added and the mixture was stirred at room temperature for 1 hour. The reaction was quenched by addition of water and the mixture was extracted with EtOAc. The organic layer was washed with water, then dried $\left(\mathrm{Na}_{2} \mathrm{SO}_{4}\right)$ and concentrated under reduced pressure. The residue was purified by silica gel column chromatography (20\%EtOAc/hexane) to give T1 (85.5 mg, $70 \%$ ) as a yellow solid, m.p. 188.5-189.5 ${ }^{\circ} \mathrm{C}$; FTIR (KBr) $v_{\max }$ : 3182, 2965, 1665, 1585, 1455, 1383, 1239, 739, 688; ${ }^{1} \mathrm{H}-\mathrm{NMR}\left(\mathrm{CDCl}_{3}\right) \delta: 9.33$ (s, $\left.1 \mathrm{H}\right), 8.29$ (d, $\left.J=2.2,1 \mathrm{H}\right), 8.09$ (d, $\left.J=2.2,1 \mathrm{H}\right), 7.34-7.20$ (m, 6H), 7.04 (d, $J=8.1,1 \mathrm{H}), 4.18$ (q, $J=7.3,2 \mathrm{H}), 4.05$ (s, 2H), 1.23 (t, $J=7.3,3 \mathrm{H}) ;{ }^{13} \mathrm{C}-\mathrm{NMR}\left(\mathrm{CDCl}_{3}\right)$ $\delta: 168.6,157.8,151.8,145.1,141.2,134.9,131.8,130.6(2 \mathrm{C}), 129.1(2 \mathrm{C}), 128.6,127.0(2 \mathrm{C}), 125.1$, 119.7, 119.6, 42.0, 35.6, 13.6; MS (EI), m/z (relative intensity): 396 ( $\left.\mathrm{M}^{+}, 7\right), 287$ (100), 259 (52), 231 (14); HRMS (ESI-TOF) calcd. for $\mathrm{C}_{20} \mathrm{H}_{18} \mathrm{ClN}_{4} \mathrm{OS}[\mathrm{M}+\mathrm{H}]^{+}$397.0884; found: 397.0894

2-Chloro-5,11-dihydro-11-ethyl-8-(3-methoxyphenylthio)-methyl-6H-dipyrido[3,2-b:2',3'-e][1,4] diazepin-6-one (T2)

A solution of 3-methoxythiophenol $(0.14 \mathrm{ml}, 1.14 \mathrm{mmol}$ ) in DMF (2 mL) was treated with 60\% sodium hydride (76 mg, $1.88 \mathrm{mmol}$ ) under a $\mathrm{N}_{2}$ atmosphere. After 10 minutes, a solution of 15 (122 
mg, $0.38 \mathrm{mmol}$ ) in DMF (3 $\mathrm{mL}$ ) was added and the mixture was stirred at room temperature for 1 hour. The reaction was quenched by addition of water and the mixture was extracted with EtOAc. The organic layer was washed with water, then dried $\left(\mathrm{Na}_{2} \mathrm{SO}_{4}\right)$ and concentrated under reduced pressure. The residue was recrystallized from hexane/EtOAc to afford T2 (140 mg, 87\%) as yellow crystals, m.p. 188-189 ${ }^{\circ}$; FTIR (KBr) $v_{\max }$ : 3181, 2965, 1662, 1589, 1458, 1385, 1229, 1044, 767, 693; ${ }^{1} \mathrm{H}-$ NMR $\left(\mathrm{CDCl}_{3}\right) \delta: 9.56$ (br s, 1H), 8.30 (d, $\left.J=2.2,1 \mathrm{H}\right), 8.08$ (d, $\left.J=2.2,1 \mathrm{H}\right), 7.33$ (d, $\left.J=8.1,1 \mathrm{H}\right), 7.18$ (t, $J=8.1,1 \mathrm{H}), 7.04$ (d, $J=8.1,1 \mathrm{H}), 6.90-6.72(\mathrm{~m}, 3 \mathrm{H}), 4.06$ (s, $2 \mathrm{H}), 3.73(\mathrm{~s}, 3 \mathrm{H}), 1.23(\mathrm{t}, J=7.3,3 \mathrm{H}) ;{ }^{13} \mathrm{C}-$ NMR $\left(\mathrm{CDCl}_{3}\right) \delta$ : 168.8, 159.9, 157.9, 151.8(2C), 145.1, 141.2, 136.2, 131.8, 129.9, 128.6, 125.2, 122.6, 119.7, 119.6, 115.8, 112.9, 55.3, 42.1, 35.4, 13.6; MS (EI), $m / z$ (relative intensity): $426\left(\mathrm{M}^{+}, 6\right)$, 287 (100), 259 (57), 231 (15); HRMS (ESI-TOF) calcd. for $\mathrm{C}_{21} \mathrm{H}_{20} \mathrm{ClN}_{4} \mathrm{O}_{2} \mathrm{~S}[\mathrm{M}+\mathrm{H}]^{+}$427.0990; found: 427.0988 .

\section{Biological methods: Materials}

DA5 (HIV-1 subtype E) cells were obtained from HIV-1 infected pregnant women. These viruses were X4 strain with the syncytium-inducing (SI) formation property, causing morphological changes (cytopathic effect) in infected cells. White blood cells: peripheral blood mononuclear cells were obtained from blood donors and used for HIV virus isolation. H9 T-lymphoblastoid cell line obtained from Medical Research Centre, UK, was used to prepare the viral stock. C8166 T-lymphoblastoid cell line was used to test the activities of bioactive compounds in all experiments. Bioactive compounds were dissolved in 70-95\% DMSO. Three anti-retroviral drugs (reverse transcriptase inhibitors) manufactured by the Government Pharmaceutical Organization (GPO), including ANTIVIR (100 mg AZT), GPO-vir (containing $200 \mathrm{mg}$ nevirapine, $150 \mathrm{mg}$ lamivudine, and $30 \mathrm{mg}$ stavudine), and NERAVIR (200 mg nevirapine), were used as controls in all experiments. All experiments were performed in duplicate.

Toxicity of bioactive compounds, anti-retroviral drugs, and DMSO against white blood cell culture.

The solutions of the bioactive compounds and anti-retroviral drugs (diluted to 10,1 , and $0.1 \mu \mathrm{g} / \mathrm{mL}$ in the culture medium), as well as DMSO (diluted to $1 \%, 0.1 \%$, and $0.01 \%$ ), were dispensed into tissue culture plates in duplicates. C8166 cells were then added into each well and examined everyday for 7 days. Moreover, the cells were counted, stained with 1\% tryphan blue in order to examine for cell viability under the microscope on day 0 , day 4 , and day 7 , and compared with drug-free control cells.

\section{Virustatic and virucidal tests}

The viruses were used at 100 TCID $_{50}$ (50\% tissue cell infectivity dose) level, which was determined by diluting the viruses in quadruplicates, and the potency of the viruses was calculated using Karber equation. Additionally, the following controls were used in all experiments: control viruses diluted to 100,10 , and 1 TCID $_{50}$ in order to verify that the viruses used in all experiments were at 100 TCID $_{50}$ level. C8166 control cells were used for cell examination throughout the experiments. Bioactive control was used to investigate the effect of the compounds on the cells. DMSO control was 
used to evaluate the effect of DMSO on virus proliferation in the cells. Anti-retroviral drug controls (AZT, GPO-vir, and Nevirapine) were used to investigate the effect of the drugs on the cells.

\section{Virustatic test}

C8166 cells were incubated with the solutions of bioactive compounds for 30 minutes. The viruses were then added into each well at 100 TCID $_{50}$ level, and the samples were further incubated for 3 hours. After that, the cells were washed 4 times, and maintained for 7 days. The culture medium was changed on day 3, and the cells were examined for cytopathic effect on days 4 and 7 . Additionally, the level of the p24 antigen in the culture medium was determined on day 7 using commercially-available ELISA kits in order to determine the $\mathrm{EC}_{50}$, which was the concentration of each bioactive compound that inhibited the viruses by $50 \%$.

\section{Virucidal test}

The viruses at 100 TCID50 level were incubated with the solutions of bioactive compounds for 1 hour. C8166 cells were then added to each well, and the samples were further incubated for 1 hour. After that, the cells were washed 4 times, and maintained for 7 days. The culture medium was changed on day 3, and the cells were examined for cytopathic effect on days 4 and 7 . Additionally, the level of the p24 antigen in the culture medium was also determined on day 7 using commercially-available ELISA kits.

\section{Acknowledgements}

We are grateful to the Thailand Research Fund (DBG4780009 for S.T., BRG4780007 for S.H., TRG4580072 for P.P. and RGJ-Ph.D. Program (3.C.KU/45/B.1) for P.S.) and to the Ministry of Education for financial support. Grateful acknowledgement is also due to Dr. Poonsakdi Ploypradith, Chulabhorn Research Institute, for his valuable suggestions.

\section{References}

1. Loveday, C. Nucleoside reverse transcriptase inhibitor resistance. J. Acquir. Immune. Defic. Syndr. 2001, 26 (Suppl1), S10-S24.

2. Deeks, S. G. Nonnucleoside reverse transcriptase inhibitor resistance. J. Acquir. Immune. Defic. Syndr. 2001, 26 (Suppl1), S25-S33.

3. Wainberg, M. A.; Friedland, G. Public health implications of antiretroviral therapy and HIV drug resistance. J. Am. Med. Assoc. 1998, 279, 1977-1983.

4. Volberding, P.; Lange, J. International perspectives on antiretroviral resistance. Introduction. $J$. Acquir. Immune. Defic. Syndr. 2001, 26 (Suppl1), S1-S2.

5. Cooley, L. A.; Lewin, S. R. HIV-1 cell entry and advances in viral entry inhibitor therapy. J. Clin. Virol. 2003, 26, 121-132.

6. De Clercq, E. Antiviral drugs in current clinical use. J. Clin. Virol. 2004, 30, 115-133. 
7. Hargrave, K. D.; Proudfoot, J. R.; Grozinger, K. G.; Cullen, E.; Kapadia, S. R.; Patel, U. R.; Fuchs, V. U.; Mauldin, S. C.; Vitous, J.; Behnke, M. L.; Klunder, J. M.; Pal, K.; Skiles, J. W.; McNeil, D. W.; Rose, J. M.; Chow, G. C.; Skoog, M. T.; Wu, J. C.; Schmidt, G.; Engel, W. W.; Eberlein, W. G.; Saboe, T. D.; Campbell, S. J.; Rosenthal, A. S.; Adams, J. Novel non-nucleoside inhibitors of HIV-1 reverse transcriptase. 1. Tricyclic pyridobenzo- and dipyridodiazepinones. $J$. Med. Chem. 1991, 34, 2231-2241.

8. O’Meara, J. A.; Yoakim, C.; Bonneau, P. R.; Bos, M.; Cordingley, M. G.; Deziel, R.; Doyon, L.; Duan, J.; Garneau, M.; Guse, I.; Landry, S.; Malenfant, E.; Naud, J.; Ogilvie, W. W.; Thavonekham, B.; Simoneau, B. Novel 8-substituted dipyridodiazepinone inhibitors with a broadspectrum of activity against HIV-1 strains resistant to non-nucleoside reverse transcriptase inhibitors. J. Med. Chem. 2005, 48, 5580-5588.

9. Cywin, C. L.; Klunder, J. M.; Hoermann, M.; Brickwood, J. R.; David, E.; Grob, P. M.; Schwartz, R.; Pauletti, D.; Barringer, K. J.; Shih, C. -K.; Sorge, C. L.; Erickson, D. A.; Joseph, D. P.; Hattox, S. E. Novel nonnucleoside inhibitors of HIV-1 reverse transcriptase. 8. 8-Aryloxymethyland 8-arylthiomethyldipyridodiazepinones. J. Med. Chem. 1998, 41, 2972-2984.

10. Pungpo, P.; Hannongbua, S.; Wolschann, P. Hologram quantitative structure-activity relationships investigations of non-nucleoside reverse transcriptase inhibitors. Curr. Med. Chem. 2003, 10, 1661-1677.

11. Morris, G. M.; Goodsell, D. S.; Halliday, R. S.; Huey, R.; Hart, W. E.; Belew, R. K.; Olson, A. J. Automated Docking Using a Lamarckian Genetic Algorithm and an Empirical Bindng Free Energy Function. J. Comput. Chem. 1998, 19, 1639-1662.

Sample availability: Contact the authors.

(C) 2007 by MDPI (http://www.mdpi.org). Reproduction is permitted for noncommercial purposes. 